$\mathbb{T}$ periodica polytechnica

Chemical Engineering

$54 / 2(2010) 8186$

doi: 10.3311/pp.ch.2010-2.04

web: http://www.pp.bme.hu/ch

(c) Periodica Polytechnica 2010

RESEARCH ARTICLE

\section{Transport of $\mathrm{NaCl}, \mathrm{MgSO}_{4}, \mathrm{MgCl}_{2}$ and $\mathrm{Na}_{2} \mathrm{SO}_{4}$ across $\mathrm{DL}$ type nanofiltration membrane}

\author{
Yahya Ramadan / György Pátzay ${ }^{1}$ / Gábor Tamás Szabó
}

Received 2009-04-28, accepted 2009-09-01

\begin{abstract}
The separation of inorganic ions by membrane filtration of aqueous solutions through NF-membranes was investigated. The single and binary salt solutions of $\mathrm{NaCl}, \mathrm{MgCl}_{2}, \mathrm{Na}_{2} \mathrm{SO}_{4}$ and $\mathrm{MgSO}_{4}$ were used in this study. These salts are the most commonly found in natural water resources. From the research literature it was stated that $\mathrm{NaCl}$ has a very low rejection range with $\mathrm{NF}$ membranes while $\mathrm{MgCl}_{2}$ is moderately rejected, $\mathrm{Na}_{2} \mathrm{SO}_{4}$ and $\mathrm{MgSO}_{4}$ are very highly rejected salts. Thus, these four salts provide a full range of rejection behavior for the $\mathrm{NF}$ system and hence constitute an ideal system. In addition, these salts have a very high solubility in water so there would not be any cake layer formed due to precipitation of salts at the surface of the membrane where a significantly higher concentration of salt can be developed due to concentration polarization.
\end{abstract}

\section{Keywords \\ Nanofiltration; Salt separation}

\section{Yahya Ramadan}

Department of Department of Chemical and Environmental Process Engineering, BME, H-1111, Budapest, Múegyetem rakpart 3, Hungary

e-mail: Ramadan@interware.hu

\section{György Pátzay ${ }^{1}$}

Department of Department of Chemical and Environmental Process Engineering, BME, H-1111, Budapest, Múegyetem rakpart 3, Hungary

e-mail: gypatzay@mail.bme.hu

\section{Gábor Tamás Szabó}

Department of Chemical and Environmental Process Engineering, BME, H1111, Budapest, Múegyetem rakpart 3, Hungary

e-mail: gtszabo@t-online.hu

\section{Introduction}

The aim of our research is to investigate the effect of an accompanying anion on the NF separation of cations by the aid of a DL membrane which is commercially available. For this rea-

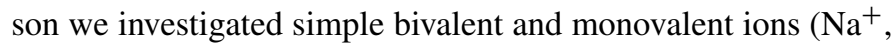
$\mathrm{Mg}^{2+}, \mathrm{Cl}^{-}, \mathrm{SO}_{4}^{2-}$ ).

Nanofiltration (NF) can be used to concentrate solutions containing multivalent salts or to fractionate salts due to the different charge densities and hydrated sizes of the ions [1-3].

Charge effects are important in salt separation using NF, for which both sieving and solution-diffusion are the major separation mechanisms [4].

The most important feature of the experimental separation data is the effect of the anion valence and the feed concentration on the salt rejections. For a given set of operating conditions, the salt rejections (R) follows the order: $R_{\mathrm{MgCl}_{2}}<\mathrm{R}_{\mathrm{MSO}_{4}}<$

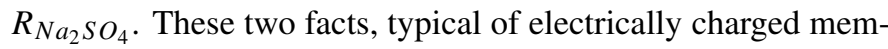
branes, are qualitatively in agreement with the ion exclusion principle [5-7]. The idea of using membrane separation as a method to concentrate $\mathrm{Na}_{2} \mathrm{SO}_{4}$ solutions from brine streams was first conceived in 1992, and between 1993-1995 the performance of a variety of commercially available NF membranes was tested using a specially designed test apparatus in Kvaerner Chemetics' laboratory. NF membranes have previously been shown to effectively separate multivalent anions, (e.g. $\mathrm{SO}_{4}^{2-}$ ) from monovalent ones, (e.g. $\mathrm{Cl}^{-}$) in dilute solutions $[8]$. Already in 1990, Rautenbach and Gröschl reported a significant decrease in $\mathrm{NaCl}$ retention when $\mathrm{Na}_{2} \mathrm{SO}_{4}$ was added to the feed solution [9]. Similar effects have also been reported when acidic salt solutions were filtered: nitric acid and sodium nitrate permeation was enhanced by the addition of magnesium nitrate and in a separate study, sulphuric acid permeation was enhanced by the addition of copper sulphate [10,11].

\section{Experimental}

The aim of our investigation was the study of the NF separation of $\mathrm{Na}^{+}$and $\mathrm{Mg}^{2+}$ ions effected by the various of accompanying anions. All the salt solutions were prepared from Ul-

${ }^{1}$ corresponding author 


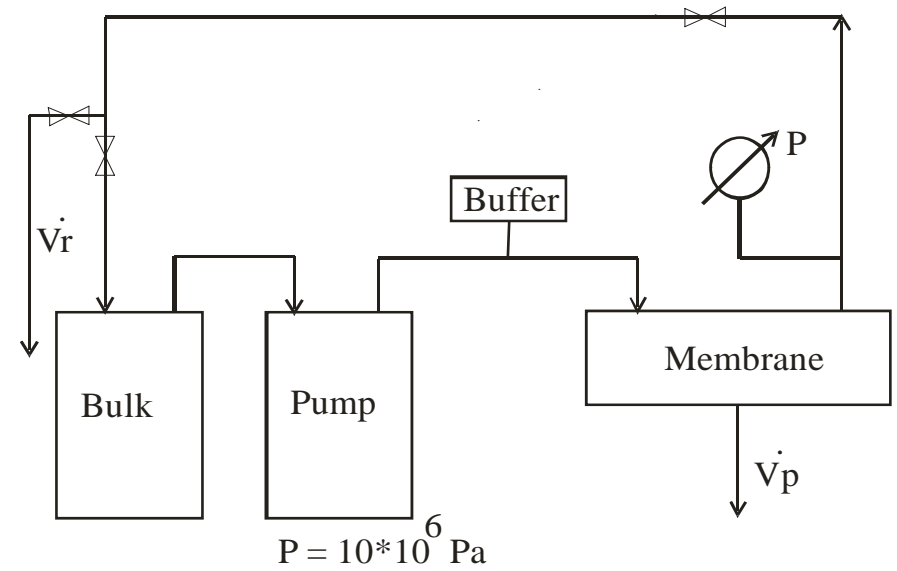

(a)
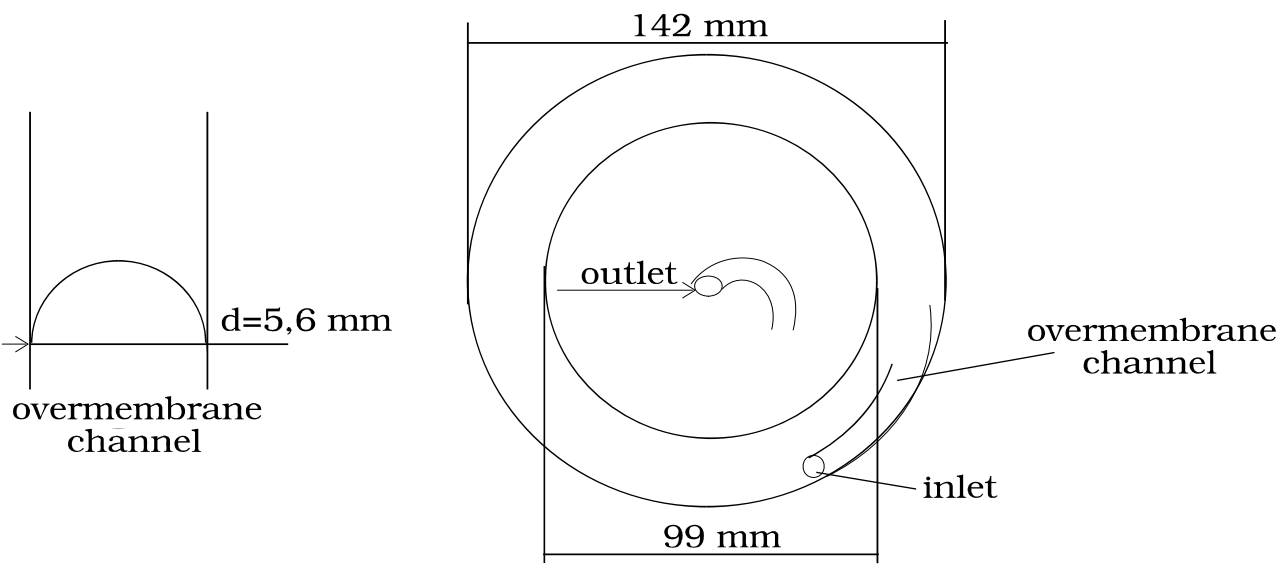

(b)

Fig. 1. (a) The experimental set. (b) Cell dimensions

tra Pure Water (UPW) with an ionic conductivity of $0.05 \mu \mathrm{S} / \mathrm{m}$ at $24^{\circ} \mathrm{C}$ and high purity salts $\mathrm{NaCl}, \mathrm{MgCl}_{2} \cdot 6 \mathrm{H}_{2} \mathrm{O}, \mathrm{Na}_{2} \mathrm{SO}_{4}$ and $\mathrm{MgSO}_{4} .7 \mathrm{H}_{2} \mathrm{O}$ purchased by Aldrich. The purified water utilized to prepare the feed solutions minimizes the biological growth before and during the experiments and also prevents the intrusion of extraneous substances in the feed solutions. In the experiments we used neutral $\mathrm{Ph}$ solutions. Our experimental arrangement is shown in Fig. 11 (a).

A commercially available flat NF membrane of a DL type was used (15\% sodium chloride retention given for $4 \mathrm{MPa}$, membrane constitution not published). The characteristics of these membranes are shown in Table1.

Dimensions of the membrane holder (supplied by Kutesz Co, Hungary) are shown in Fig. 1 (b). The membrane holder, the pump and the valves were constructed of stainless steel, and connected with polyamide tubing.

Tab. 1. Characteristics of the NF membrane used

\begin{tabular}{lllll}
\hline Membrane & company & $\begin{array}{l}\text { MWCO } \\
(\mathrm{Da})\end{array}$ & Material & $\begin{array}{l}\text { Recommended } \\
\mathrm{pH} \text { range }\end{array}$ \\
\hline $\mathrm{DL}$ & DESAL & 490 & polyamid & $2-11$ \\
\hline
\end{tabular}

In our experiments we circulated a bulk solution with the concentrate recirculation monitoring the nearly constant composi- tion of the permeate as a function of time, until a steady state was achieved. In each separation experiment we used a constant feed flow rate $7.810^{-3} \mathrm{~m}^{3} / \mathrm{h}$ and the concentrate was recirculated to the feed tank.

Fig. 2 shows the concentrate and permeate concentrations as a function of time. According to the figure the permeate concentrations are changing slightly and reaching a steady value, while the concentrate concentration is increasing during all experiments.

\section{Analytical methods}

The sodium and magnesium content was measured by ion chromatography. (type: Metrohm 861 Advanced compact IC, Metrohm 837 IC combi degasser, Metrohm 771 IC compact interface, Metrosep C3 250 cation exchange column, eluent: $5.0 \mathrm{mM} \mathrm{HNO} 3$, conductivity detector). The chloride and sulphate concentration was measured by ion chromatography using a Metrosep A Supp 4. 250/4.0 anion exchange column and 1.8 $\mathrm{mM} \mathrm{Na}_{2} \mathrm{CO}_{3}$ and $1.7 \mathrm{mM} \mathrm{NaHCO}_{3}$ solutions after the preceding calibration. 


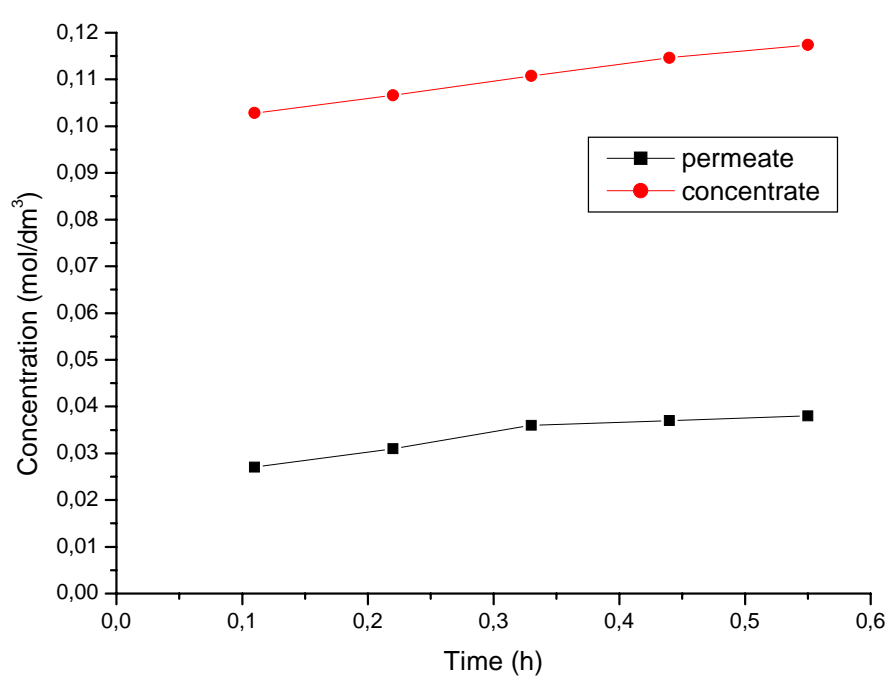

Fig. 2. Evolution the concentrate and permeate concentration as a function of time

\section{Calculations}

Transmission ( $\mathrm{Tr}$ ) of components through the NF membrane was calculated according to Eq. (1):

$$
\operatorname{Tr}(\%)=\frac{C_{p}}{C_{r}} \cdot 100
$$

where $C_{p}\left[\mathrm{~mol} / \mathrm{dm}^{3}\right]$ is the concentration of a component in the permeate and $C_{r}\left[\mathrm{~mol} / \mathrm{dm}^{3}\right]$ the concentration of the same component in the retentate.

\section{Results}

A predetermined quantity of salt was mixed in a known volume of deionized water to prepare the feed solution of desired concentration. These salts have a very high solubility in water at room temperature $\left(22 \sim 26{ }^{0} \mathrm{C}\right)$ so there would not be any cake layer formed due to precipitation of salts at the surface of membrane where significantly higher concentration of salt can be developed due to concentration polarization.

\subsection{Investigation of $\mathrm{NaCl}$ solution}

First we conducted the nanofiltration of UPW water containing $0.1 \mathrm{~mol} / \mathrm{dm}^{3} \mathrm{NaCl}$ through the DL nanofiltrating membrane. We measured the sodium and chloride ion concentrations and calculated the transmission values by Eq. (1) (Table 2) we created a graph using the measured data, which showed the single ion transmission in relation to the volume of the permeate (Fig. 3).

In case of $\mathrm{NaCl}$ separation the curves of the single ion transmission of the sodium and chloride ions overlap, indicating that the sodium and chloride ions are passing the membrane together. It is clear from the experiment, that the transmission of the $\mathrm{Na}^{+}$as well as the $\mathrm{Cl}^{-}$ions through the nanofiltration membrane are high.

\subsection{Investigation of $\mathrm{MgCl}_{2}$ solution}

The $\mathrm{MgCl}_{2}$ solution can be considered as a type 2-1 system: it consists of a bivalent cation and two monovalent anions. Ac-
Tab. 2. $\mathrm{NaCl}$ transmission in the $\mathrm{DL}$ membrane $\left(\mathrm{t}=25^{\circ} \mathrm{C}, \mathrm{p}=10\right.$ bar $)$

\begin{tabular}{lll}
\hline $\begin{array}{l}\text { The volume of permate } \\
\mathrm{Vp}\left(\mathrm{cm}^{3}\right)\end{array}$ & $\begin{array}{l}\left.\operatorname{Tr}_{(\mathrm{Na}}+\right) \\
(\%)\end{array}$ & $\begin{array}{l}\operatorname{Tr}_{\left(\mathrm{Cl}^{-}\right)} \\
(\%)\end{array}$ \\
\hline 20 & 75 & 77 \\
40 & 80 & 83 \\
60 & 81 & 83.5 \\
80 & 86 & 85 \\
100 & 88 & 85 \\
\hline
\end{tabular}

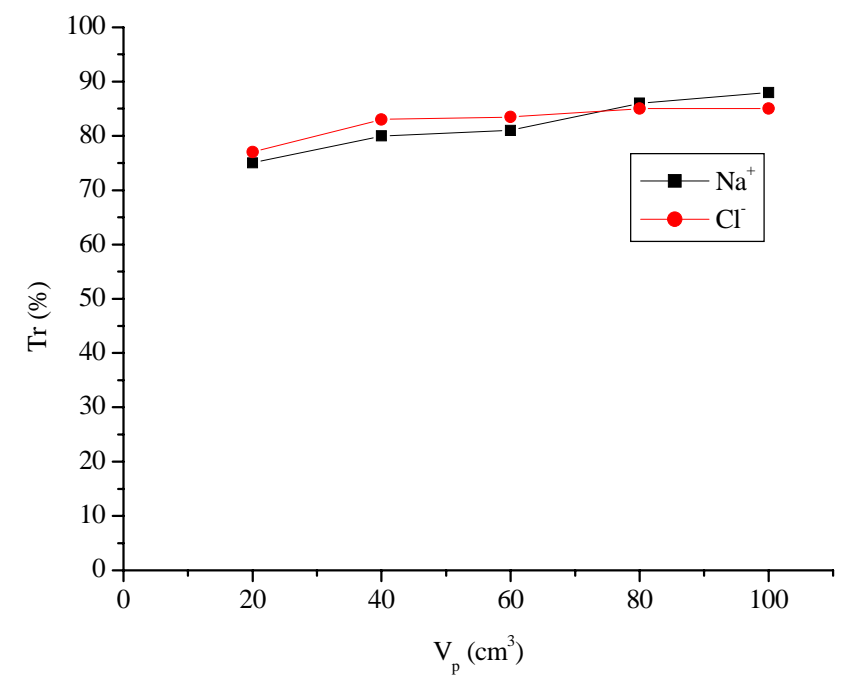

Fig. 3. $\mathrm{NaCl}$ transmission as a function of the volume of permate

cording to the data in the literature, in the case of multivalent ions, the ion transmission through the NF membranes is significantly lower than that of the monovalent ions. It may sound surprising that although magnesium is bivalent and is a relatively large cation, its ion transmission is highly siginficant through NF membranes. The explanation of this phenomenon is that a tension difference occurs on the membrane in the beginning of the diffusion process. As the diffusion coefficient of the chloride ions measured at the water solution is much larger than that of the magnesium ions (Table 3), in a given period of time of the ions on the larger concentration side of the membrane, the chloride ions get further within the membrane than the magnesium ions. Thus, an electric field develops and the initially smaller concentration side will be more negative than the other side. This field will slow down the diffusion of the chloride ions and accelerate that of the magnesium ions. This field is called a diffusion field. The diffusion field facilitates the diffusion of the chloride ions and magnesium ions to diffuse with nearly the same rate (Table 4 and Fig. 4).

Tab. 3. Diffusion constant of some ions measured in water solution at $25{ }^{\circ} \mathrm{C}$ 1213

\begin{tabular}{lc}
\hline Ion & $\mathrm{D}_{0}\left(\times 10^{-10} \mathrm{~m}^{2} / \mathrm{s}\right)$ \\
\hline $\mathrm{Na}^{+}$ & 13,3 \\
\hline $1 / 2 \mathrm{Mg}^{2+}$ & 7,05 \\
$\mathrm{Cl}^{-}$ & 20,3 \\
$1 / 2 \mathrm{SO}_{4}^{2-}$ & 10,7 \\
\hline
\end{tabular}


Tab. 4. $\mathrm{MgCl}_{2}$ transmission in the DL membrane $\left(\mathrm{t}=25^{\circ} \mathrm{C}, \mathrm{p}=10\right.$ bar $)$

\begin{tabular}{lll}
\hline $\begin{array}{l}\text { The volume of permate } \\
\mathrm{Vp}\left(\mathrm{cm}^{3}\right)\end{array}$ & $\begin{array}{l}\operatorname{Tr}_{\left(\mathrm{Mg}^{2+}\right)} \\
(\%)\end{array}$ & $\begin{array}{l}\operatorname{Tr}_{\left(\mathrm{Cl}^{-}\right)} \\
(\%)\end{array}$ \\
\hline 20 & 28 & 27 \\
40 & 29 & 31 \\
60 & 33 & 32 \\
80 & 33 & 33 \\
100 & 33 & 33 \\
\hline
\end{tabular}

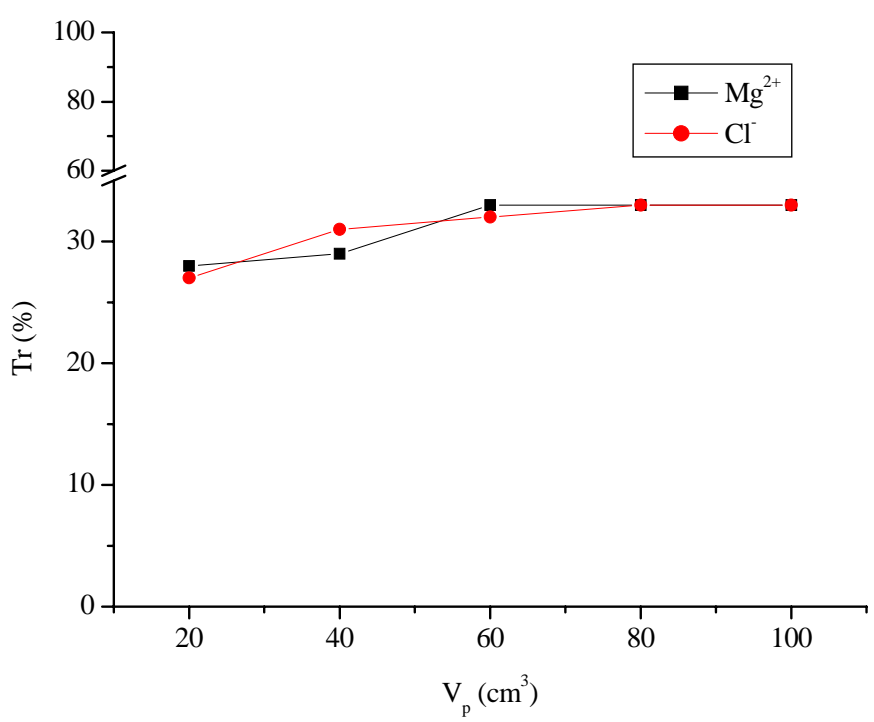

Fig. 4. $\mathrm{MgCl}_{2}$ transmission as a function of the volume of permate

In the case of $\mathrm{MgCl}_{2}$ separation, the curves of the single ion transmission of the magnesium and chloride ions overlap, indicating that the cation goes through the membrane at the same time as the anions. It is clear from the experiment that the transmission of the $\mathrm{Mg}^{2+}$ comma goes here as well as the $\mathrm{Cl}^{-}$ions through the nanofiltration membrane are not too high.

\subsection{Investigation of $\mathrm{Na}_{2} \mathrm{SO}_{4}$ solution}

The $\mathrm{Na}_{2} \mathrm{SO}_{4}$ solution is a type 1-2 system. It is seen from the transmission curves (Fig. 5) that the transmission of the ions is determined by the bivalent and large sized sulphate ion. The transmission of the sodium ion through the DL type membranes is under $7 \%$. As the diffusion constant measured in water solution of the sulphate ions is smaller than that of the sodium ions (Table 3), in a given period of time of the ions on the membrane concentrate, sodium ions get further within the membrane than the sulphate ions. Thus an electric field will develop and initially one side of the permeate will be more positive than the other. This field will slow down the diffusion of the sodium ions and accelerate that of the sulphate ions. From this it is evident that the sulphate ions slow down the transmission of the sodium ions through the membrane (Table 5).

It is evident from the experiments that the transmission of the $\mathrm{Na}^{+}$and the $\mathrm{SO}_{4}^{2-}$ ions through the nanofiltration membrane is low.
Tab. 5. $\mathrm{Na}_{2} \mathrm{SO}_{4}$ transmission in the DL membtane $\left(\mathrm{t}=25^{\circ} \mathrm{C}, 10\right.$ bar $)$

\begin{tabular}{lll}
\hline $\begin{array}{l}\text { The volume of permate } \\
\mathrm{Vp}\left(\mathrm{cm}^{3}\right)\end{array}$ & $\begin{array}{l}\operatorname{Tr}_{\left(\mathrm{Na}^{+}\right)} \\
(\%)\end{array}$ & $\begin{array}{l}\mathrm{Tr}_{\left(\mathrm{SO}_{4}^{2-}\right)} \\
(\%)\end{array}$ \\
\hline 20 & 5.0 & 4.5 \\
40 & 6.0 & 5.0 \\
60 & 6.7 & 5.3 \\
80 & 7.0 & 5.5 \\
100 & 7.0 & 5.8 \\
\hline
\end{tabular}

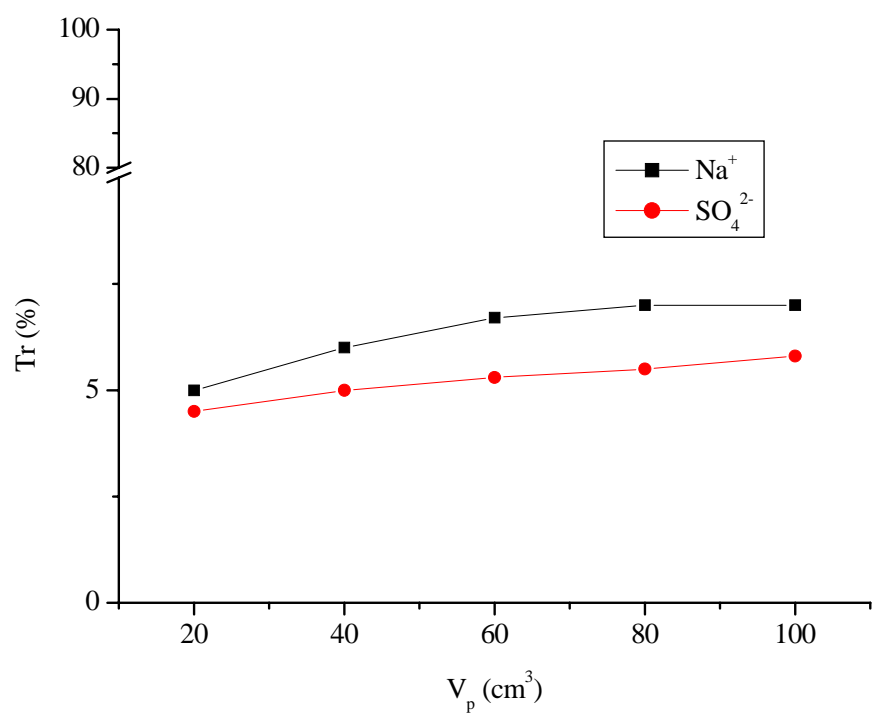

Fig. 5. $\mathrm{Na}_{2} \mathrm{SO}_{4}$ transmission as a function of the volume of permate

\subsection{Investigation of $\mathrm{MgSO}_{4}$ solution}

$\mathrm{MgSO}_{4}$ is a 2-2 system. It is seen from the measured ion transmission curves (Fig. 6) that the ion transmission is very small through the DL type membrane for both the magnesium ions and the sulphate ions. The sulphate ion has a slowing effect on the transmission of the magnesium ion. We made a graph using the measured data, on which the specific ion transmissions can be seen together with the curve of the permeate volume (Table 6 .

Tab. 6. $\mathrm{MgSO}_{4}$ transmission in the DL membrane $\left(\mathrm{t}=25^{\circ} \mathrm{C}, \mathrm{p}=10\right.$ bar $)$

\begin{tabular}{lll}
\hline $\begin{array}{l}\text { The volume of permate } \\
\mathrm{Vp}\left(\mathrm{cm}^{3}\right)\end{array}$ & $\begin{array}{l}\operatorname{Tr}_{(\mathrm{Mg}}^{2+)} \\
(\%)\end{array}$ & $\begin{array}{l}\mathrm{Tr}_{\left(\mathrm{SO}_{4}^{2-}\right)} \\
(\%)\end{array}$ \\
\hline 20 & 2.3 & 3.0 \\
40 & 2.3 & 2.6 \\
60 & 2.4 & 2.5 \\
80 & 3.0 & 2.5 \\
100 & 3.0 & 2.6 \\
\hline
\end{tabular}

In case of $\mathrm{MgSO}_{4}$ separation the curves of the specific ion transmissions are overlapping, showing that the cations get through the membrane together with the anions. It is evident from the experiments that the transmission of the $\mathrm{Mg}^{2+}$ and the $\mathrm{SO}_{4}^{2-}$ ions through the nanofiltration membrane is low. 


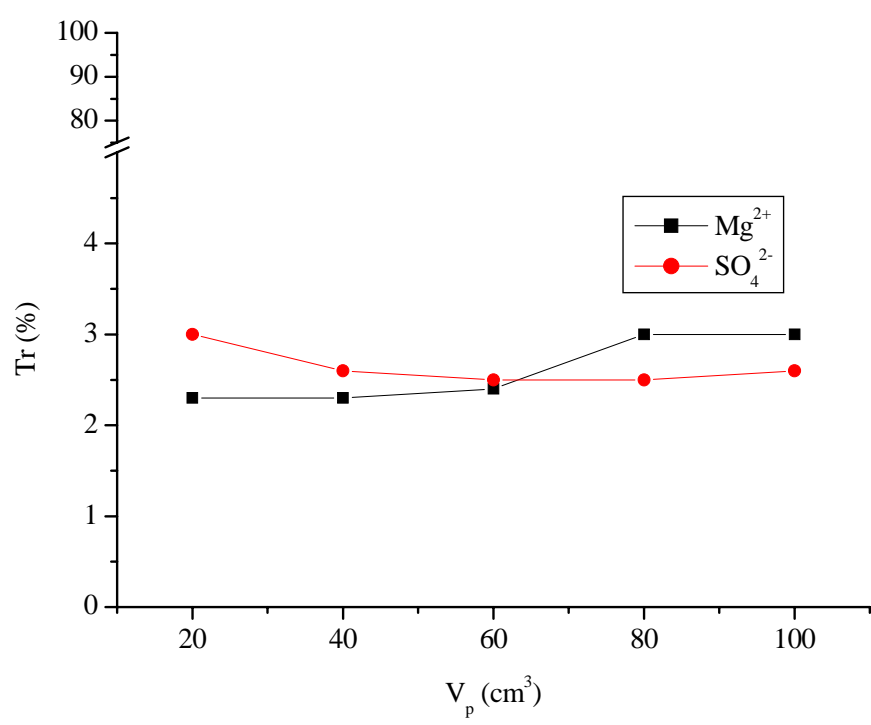

Fig. 6. $\mathrm{MgSO}_{4}$ transmission as a function of the volume of permate

5.5 Investigation of the mixture of $\mathrm{NaCl}$ and $\mathrm{MgSO}_{4}$ solutions

In this part of the experiment we made a mixture of 0.1 $\mathrm{mol} / \mathrm{dm}^{3} \mathrm{NaCl}$ solution (1-1 system) and of $0.1 \mathrm{~mol} / \mathrm{dm}^{3}$ $\mathrm{MgSO}_{4}$ solution (2-2 system) and conducted the experiment under pressure of 10 bar. The measurement data and results are shown in Table 7 and Fig.7

Tab. 7. $\mathrm{NaCl}$ and $\mathrm{MgSO}_{4}$ transmission in the $\mathrm{DL}$ membrane $\left(\mathrm{t}=25^{\circ} \mathrm{C}\right.$, $\mathrm{p}=10$ bar)

\begin{tabular}{lllll}
\hline $\begin{array}{l}\text { The volume of } \\
\text { permate }\end{array}$ & $\begin{array}{l}\operatorname{Tr}_{\left(\mathrm{Na}^{+}\right)} \\
(\%)\end{array}$ & $\begin{array}{l}\mathrm{Tr}_{\left(\mathrm{Mg}^{2+}\right)} \\
(\%)\end{array}$ & $\begin{array}{l}\mathrm{Tr}_{\left(\mathrm{Cl}^{-}\right)} \\
(\%)\end{array}$ & $\begin{array}{l}\mathrm{Tr}_{\left(\mathrm{SO}_{4}^{2-}\right)} \\
(\%)\end{array}$ \\
\hline 20 & 68 & 12 & 81 & 3.0 \\
40 & 72 & 13 & 87 & 2.6 \\
60 & 71 & 15 & 88 & 2.3 \\
80 & 73 & 8 & 89 & 2.4 \\
100 & 73 & 7 & 90 & 2.5 \\
\hline
\end{tabular}

The transmission of the sulphate and magnesium double charged ions is smaller than that of the sodium and chloride ion. The transmission of magnesium in this multicomponent a solution is higher than in a single $\mathrm{MgSO}_{4}$ solution (Table 6). The explanation to this phenomenon is that the original ions from the dissolved salts $\left(\mathrm{MgSO}_{4}, \mathrm{NaCl}\right)$ are slightly exchanged, i.e., some magnesium passed the membrane with two chloride anions.

5.6 Investigation of the mixture of $\mathrm{MgCl}_{2}$ and $\mathrm{Na}_{2} \mathrm{SO}_{4}$ solutions

For this experiment we made a $0.1 \mathrm{~mol} / \mathrm{dm}^{3} \mathrm{MgCl}_{2}$ (2-1) system and a $0.1 \mathrm{~mol} / \mathrm{dm}^{3} \mathrm{Na}_{2} \mathrm{SO}_{4}(1-2)$ system solution. When all four ions $\left(\mathrm{Na}^{+}, \mathrm{Mg}^{2+}, \mathrm{Cl}^{-}, \mathrm{SO}_{4}^{2-}\right)$ are in the solution, the differences between the monovalent and bivalent ions become clearly visible. The measurement data and results are shown in Table 8 and Fig. 8 .

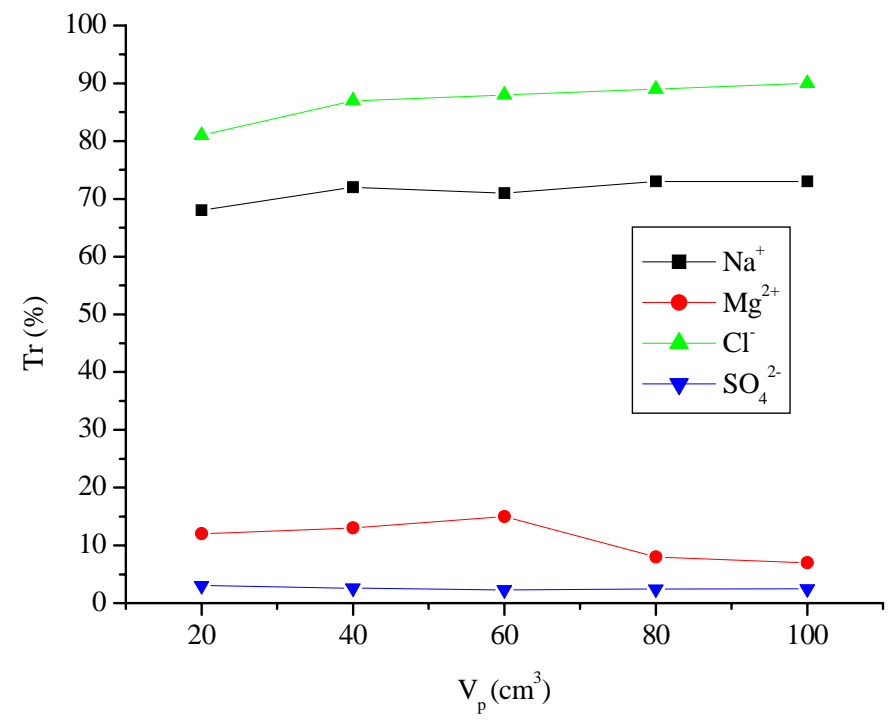

Fig. 7. $\mathrm{NaCl}$ and $\mathrm{MgSO}_{4}$ transmission as a function of the volume of permate

Tab. 8. $\mathrm{MgCl}_{2}$ and $\mathrm{Na}_{2} \mathrm{SO}_{4}$ transmission in the DL membrane $\left(\mathrm{t}=25^{\circ} \mathrm{C}\right.$, $\mathrm{p}=10$ bar)

\begin{tabular}{lllll}
\hline $\begin{array}{l}\text { The volume of } \\
\text { permate } \\
\mathrm{Vp}\left(\mathrm{cm}^{3}\right)\end{array}$ & $\begin{array}{l}\operatorname{Tr}_{(\mathrm{Na+})} \\
(\%)\end{array}$ & $\begin{array}{l}\operatorname{Tr}_{\left(\mathrm{Mg}^{2+}\right)} \\
(\%)\end{array}$ & $\begin{array}{l}\left.\operatorname{Tr}_{(\mathrm{Cl}}\right) \\
(\%)\end{array}$ & $\begin{array}{l}\operatorname{Tr}_{\left(\mathrm{SO}^{2-}\right)} \\
(\%)\end{array}$ \\
\hline 20 & 68 & 10 & 83 & 2 \\
40 & 72 & 10 & 91 & 2 \\
60 & 75 & 9 & 91 & 2 \\
80 & 75 & 9 & 90 & 2 \\
100 & 75 & 9 & 89 & 2 \\
\hline
\end{tabular}

This experiment had interesting results. The transmission of chloride and sodium in the multicomponent solution is higher than for pure $\mathrm{MgCl}_{2}$ solution and $\mathrm{Na}_{2} \mathrm{SO}_{4}$ solution (Tables 4 and 5). The explanation to this phenomenon is that the original ions from dissolved salts are heavily exchanged, i.e., most of the sodium crosses the membrane with a chloride anion.

\section{Conclusions}

In the case of bivalent ions, irrespective of their charge, the ion transmission is smaller than in the case of the monovalent ions. In the course of the experiments we found that during the creation of the multicomponent solution $\left(\mathrm{MgCl}_{2}, \mathrm{Na}_{2} \mathrm{SO}_{4}, \mathrm{NaCl}\right.$ and $\left.\mathrm{MgSO}_{4}\right)$ a ligand exchange happened between $\mathrm{MgCl}_{2}$ and $\mathrm{Na}_{2} \mathrm{SO}_{4}$. The two anions changed places (ligandum change) and large ion pairs were created which goes through the membrane with difficulty.

These phenomena observed could cause a new possibility of increasing the separation efficiency of monovalue ions from a multicomponent system by the aid of nanofiltrating membranes. These results can be applied for example, in the treatment of regeneration solutions of sodium cycle ion exchanges using nanofiltration, and in the treatment of galvanic industry wastewater. 


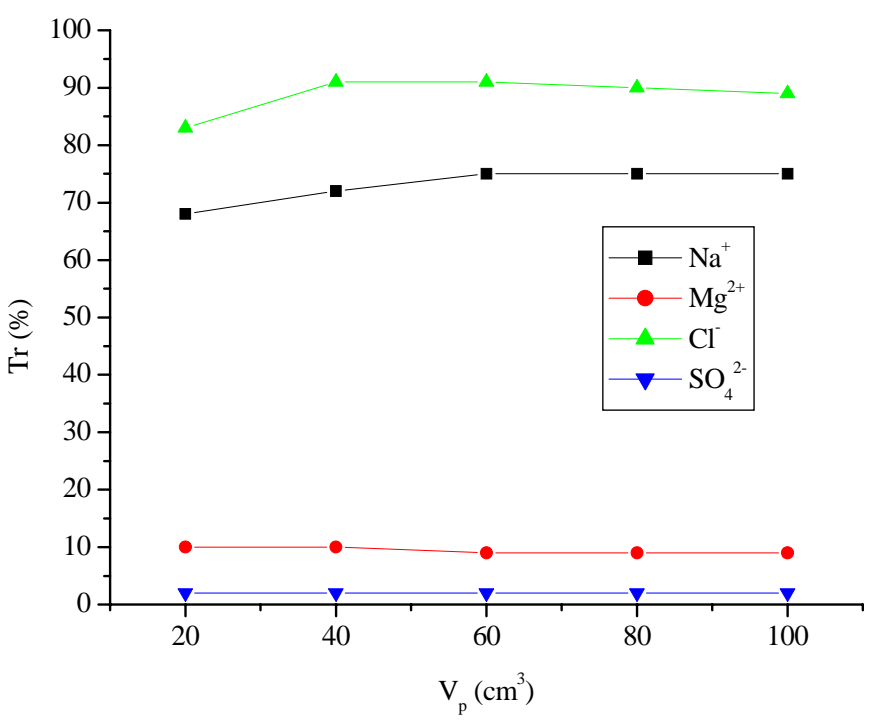

Fig. 8. $\mathrm{MgCl}_{2}$ and $\mathrm{Na}_{2} \mathrm{SO}_{4}$ transmission as a function of the volume of permate

\section{Nomenclature}

$\mathrm{C}\left(\mathrm{mol} / \mathrm{dm}^{3}\right): \quad$ Ion concentration in the feed $\mathrm{C}_{p}\left(\mathrm{~mol} / \mathrm{dm}^{3}\right)$ : Ion concentration in the permeate $\mathrm{C}_{r}\left(\mathrm{~mol} / \mathrm{dm}^{3}\right)$ : Ion concentration in the retentate $\operatorname{Tr}(\%): \quad$ Ionic transmission $\mathrm{V}_{p}\left(\mathrm{~m}^{3} / \mathrm{h}\right)$ $\mathrm{V}_{\dot{r}}\left(\mathrm{~m}^{3} / \mathrm{h}\right):$ Flow of the permeate Flow of the retentate $\mathrm{Vp}\left(\mathrm{cm}^{3}\right)$ :

\section{References}

1 Tanninen J, Importance of Charge in Nanofiltration, Finland, 2004. $\mathrm{PhD}$ Thesis.

2 Gamal Khedr M, Nanofiltration and low energy reverse osmosis for rejection of radioactive isotopes and heavy metal cations from drinking water sources, Desalination and Water Treatment 2 (2009), 342-350.

3 Szöke Sz, Pátzay Gy, Weiser L, Cobalt(III) EDTA complex removal from aqueous alkaline borate solutions by nanofiltration, Desalination 175 (2005), no. 2, 179-185.

4 Mulder M H V, Voorthuizen E M, Peeters J M M, Nanofiltration: Principles and Applications (Schäfer A I, Fane A G, Waite T D, eds.), Elsevier Advanced Technology, Oxford, 2005.

5 Sachs S B, Zisner E, Herscovici G, Hybrid reverse osmosis-ultrafiltration membranes, Desalination 18 (1976), 99-111.

6 Simpson A E, Kerr C A, Buckley C A, The effect of pH on the nanofiltration of the carbonate system in solution, Desalination 64 (1987), 305-319.

7 Afonso M D, de Pinho M N, Transport of $\mathrm{MgSO}_{4}, \mathrm{MgCl}_{2}$, and $\mathrm{Na}_{2} \mathrm{SO}_{4}$ across an amphoteric nanofiltration membrane, Journal of Membrane Science 179 (2000), 137-154.

8 Barr A, Sulphate removal by nanofiltration, Filtration \& Separation 38 (2001), 18-20.

9 Rautenbach R, Gröschl A, Separation potential of nanofiltration membranes, Desalination 77 (1990), 73-84.

10 Tanninen J, Nyström M, Separation of ion sin acidic conditions using $N F$, Desalination 147 (2002), 295-299.

11 Tanninen J, Platt S, Nyström M, Separation of sulphuric acid in metal sulphate solutions, IMSTEC'03 Referred Proc., 10-14.11.2003. (CD).

12 Quigley R M, Yanful E K, Fernandez F, Ion transfer by diffusion through Claey Baniers, Proc. Geotechnical Practice for Waste Disposal, Geotechnical Special Publications 13, pp. 137-158.

13 Lerman A, Geotechnical Processes - Water and Sediment Envirinments, Wiley and Sons. 